\title{
Bacterioplankton dynamics in the Gulf of Aqaba and the northern Red Sea in early spring
}

\author{
Hans-Peter Grossart ${ }^{*}$, Meinhard Simon
}

Institute for Chemistry and Biology of the Marine Environment, University of Oldenburg, 26111 Oldenburg, Germany

\begin{abstract}
The northern Red Sea, with its northernmost extension the Gulf of Aqaba, is an oligotrophic marine ecosystem, for which the growth and substrate dynamics of the heterotrophic bacterioplankton have not yet been studied. In 1999, we carried out a comprehensive investigation of bacterioplankton growth dynamics in early spring (February/March), a time of year when the Gulf waters are deeply mixed, while permanent stratification prevails in the northern Red Sea. Most of the parameters measured yielded low values (bacterial numbers: 0.5 to $12.8 \times 10^{5} \mathrm{ml}^{-1}$; production: 0.9 to $56.8 \mathrm{ng} \mathrm{C} \mathrm{l}^{-1} \mathrm{~h}^{-1}$; growth rates: $<0.01$ to $0.15 \mathrm{~d}^{-1}$; turnover rates of dissolved free amino acids, DFAA: 0.008 to $1.35 \mathrm{~d}^{-1}$; glucose: 0.001 to $0.14 \mathrm{~d}^{-1}$; and concentrations of dissolved free neutral monosaccharides: <2 to $86 \mathrm{nM})$. Glucose was the only monosaccharide detected in $93 \%$ of the samples. Concentrations of DFAA ranged from 13.2 to $176 \mathrm{nM}$, and those of dissolved combined amino acids and neutral monosaccharides from 0.42 to $3.69 \mu \mathrm{M}$ and 0.05 to $3.31 \mu \mathrm{M}$, respectively. Uptake of glucose (as percent of bacterial production) in $93 \%$ of the samples was $<50 \%$, whereas that of DFAA was much higher, often exceeding $100 \%$ (the latter result may have been due to methodological biases). Most of the parameters measured were more variable and covered a wider range in the northern Red Sea than in the Gulf, where vertical patterns were more homogenous. Only concentrations of dissolved free neutral monosaccharides were systematically lower in the northern Red Sea. Bacterial production in this area was significantly correlated with turnover and uptake rates of DFAA, and with glucose turnover rates below $100 \mathrm{~m}$. Aminopeptidase and $\beta$-glucosidase activities were fairly similar in both study areas, with means ranging from 19.4 to $29.9 \mathrm{nmol} \mathrm{l}^{-1} \mathrm{~h}^{-1}$. Whereas aminopeptidase hydrolysis rates were in the same range as values found in other oceanic regions, $\beta$-glucosidase hydrolysis rates were much higher, possibly due to the persistence of active $\beta$-glucosidase in the dissolved phase, as has been reported for alkaline phosphatase in this area. Analysis of the data indicates that in the northern Red Sea bacterioplankton growth dynamics were mainly controlled by biological processes, whereas in the Gulf hydrographic processes were more important.
\end{abstract}

KEY WORDS: Bacteria - Bacterial production · Amino acids · Carbohydrates · Turnover rates · Aminopeptidase $\cdot$ Glucosidase $\cdot$ Gulf of Aqaba $\cdot$ Red Sea

\section{INTRODUCTION}

The microbial loop (Azam et al. 1983), including heterotrophic and autotrophic picoplankton and mixoand heterotrophic nanoflagellates, has been shown to be most important in oligotrophic pelagic ecosystems such as the central oceanic gyres in tropical and subtropical regions, which are stratified and thus perma-

*E-mail: hgrossart@icbm.de nently nutrient-depleted. Most of the flow of energy and nutrient recycling (i.e. regenerated production) in these systems is mediated by trophic compartments of the microbial loop, whereas the participation of largersized compartments and thus export production is of relatively low significance (Eppley \& Peterson 1979, Li et al. 1992, Buck et al. 1996). However, several studies have indicated that grazing of picoplankton by pelagic tunicates may be another sink, and may shortcut the flux of organic matter from the microbial loop to 
higher trophic levels in oligotrophic marine ecosystems (Deibel 1982, Crocker et al. 1991, Acuña et al. 1996, Sommer et al. 2002). As one of the core components of the microbial loop, heterotrophic bacteria have been studied quite extensively in various stratified oceanic regions (Ducklow 1993, 1999, Kirchman et al. 1995, Rich et al. 1996, Goosen et al. 1997, Pedrós-Alió et al. 1999). Detailed simultaneous studies on bacterioplankton growth dynamics (including substrate availability, polymer hydrolysis and turnover and growth response) in these regions, however, are still rare (Christian \& Karl 1995, Rich et al. 1996, Keil \& Kirchman 1999).

The Red Sea, with its northernmost extension, the Gulf of Aqaba (165 km long $\times 15 \mathrm{~km}$ wide), is one of such highly oligotrophic regions in which autotrophic picoplankton and phytoplankton of $<8 \mu \mathrm{m}$ dominate the total phytoplankton biomass. Chlorophyll a (chl a) does not exceed $0.8 \mu g \mathrm{l}^{-1}$ (Lindell \& Post 1995) because of strong bottom-up control of phytoplankton growth (Sommer 2000). Whereas the Red Sea is per-

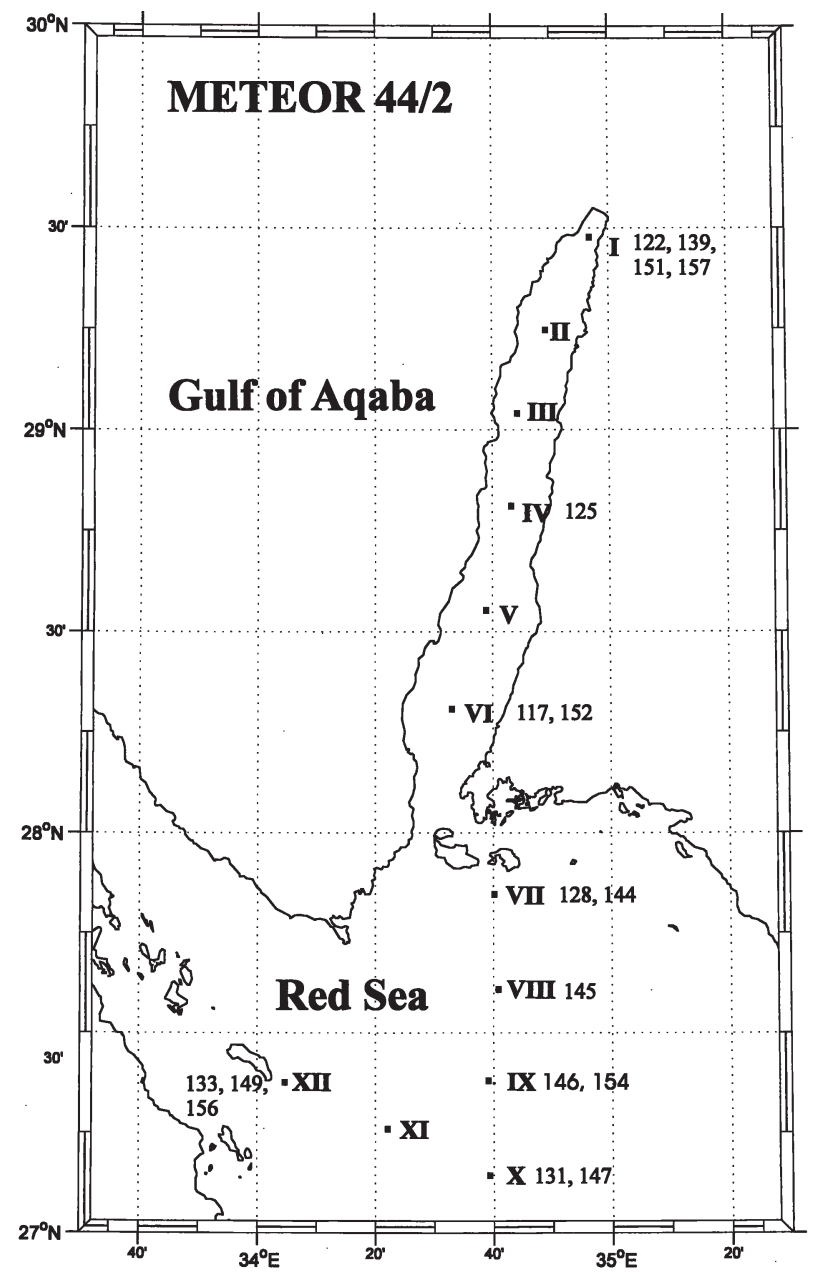

Fig. 1. Map of the study area. Numbers are sampling sites and station nos. as in Table 1 manently stratified, the Gulf of Aqaba, with a maximum depth of $1800 \mathrm{~m}$, is characterized by deep winter mixing bringing high amounts of inorganic nutrients into the otherwise nutrient-depleted euphotic zone (Wolf-Vecht et al. 1992). Water exchange with the northern Red Sea occurs via the shallow (242 m) Strait of Tiran, with a near-surface inflow into the Gulf and an underlying outflow. Growth dynamics and the composition of the autotrophic picoplankton and bacteria grazed by heterotrophic nanoflagellates have been studied in this region (Weisse 1989, Lindell \& Post 1995). Virtually nothing is known, however, about the substrate and growth dynamics of the heterotrophic bacterioplankton. In order to better evaluate and understand the significance of the microbial loop for pelagic trophodynamics in the Red Sea and the Gulf of Aqaba, it is essential to examine bacterioplankton trophodynamics in this area.

During Cruise M44/2 of RV 'Meteor' we studied substrate and growth dynamics of the heterotrophic bacterioplankton in the northern Red Sea and the Gulf of Aqaba in late February and early March 1999. This gave us the opportunity to compare the typical stratified situation of the northern Red Sea with the deeply mixed Gulf of Aqaba. Further, the simultaneous assessment of phytoplankton growth dynamics and grazing by proto-and metazooplankton enabled us to comprehensively evaluate the significance of the microbial loop during early spring in this region.

\section{MATERIALS AND METHODS}

The study was carried out during Cruise M44/2 of RV 'Meteor' between 21 February and 9 March 1999. For details of the hydrography and biology of the Gulf of Aqaba see Reiss \& Hottinger (1984), Wolf-Vecht et al. (1992), and Lindell \& Post (1995). During the cruise 12 sites were visited, but we sampled only 3 sites of a transect across the Gulf of Aqaba and 5 sites in the northern Red Sea (Fig. 1, Table 1). Several sites were visited at least twice. Water from various depths between the surface and $500 \mathrm{~m}$ was collected with $12 \mathrm{l}$ Go-Flo bottles mounted on a CTD rosette from which subsamples were withdrawn into 11 polyethylene (PE) flasks for further measurements.

Bacterial numbers. Samples for enumerating bacteria were fixed with $2 \%$ formalin. Enumeration was done by epifluorescence microscopy according to Porter \& Feig (1980). Within $2 \mathrm{~h}$ of sampling, 2 to $5 \mathrm{ml}$ were stained with DAPI (4,6-diamidinophenylindole) for 3 to $5 \mathrm{~min}$, filtered through $0.2 \mu \mathrm{m}$ black Nuclepore filters, and stored frozen at $-20^{\circ} \mathrm{C}$ until enumeration in the laboratory 6 mo later. Bacterial numbers were determined at $1000 \times$ magnification with an epifluores- 
cence microscope (Axioscope 2, Zeiss) and an imageanalysis system (analysSIS, Soft Imaging System). At least 20 view fields were counted to minimize standard deviations $(\leq 10 \%)$. We determined 20 size classes between $\leq 0.2$ and $2.0 \mu \mathrm{m}$, but $\geq 85 \%$ of all measured bacteria were between 0.2 and $0.4 \mu \mathrm{m}$ in size.

Bacterial production. Rates of bacterial biomass production were determined by the incorporation of ${ }^{14}$ C-leucine (Kirchman et al. 1985, Simon \& Azam 1989). Subsamples of $10 \mathrm{ml}$ were withdrawn into clean polystyrene test tubes. Triplicates and a formalin-killed control were labelled with ${ }^{14} \mathrm{C}$-leucine (10.8 GBq mmol ${ }^{-1}$, Hartmann Analytic) at a final concentration of $10 \mathrm{nM}$. Incubation was in the dark at in situ temperature, and was stopped after 2.5 to $5 \mathrm{~h}$ by adding formalin ( $2 \%$ final concentration). After fixation, samples were filtered onto $0.45 \mu \mathrm{m}$ nitrocellulose filters (Sartorius), rinsed with ice-cold particle-free seawater, and extracted with ice-cold 5\% trichloroacetic acid (TCA) for $5 \mathrm{~min}$. After rinsing the extracted filters twice with ice-cold $5 \%$ TCA, the filters were dissolved with ethylacetate and radioassayed by liquid scintillation counting. Biomass production was calculated from leucine incorporation rates using a conversion factor of $3.0 \mathrm{kgC}$ (mol leucine $)^{-1}$ (Simon \& Azam 1989). The coefficient of variation $(\mathrm{CV}$, standard deviation/mean) of the triplicate measurements usually was $<0.10$.

Turnover rates of dissolved free amino acids (DFAA) and dissolved free monosaccharides (DFCHO). Turnover rates of a mixture of $16{ }^{3} \mathrm{H}$-amino acids (Amersham, mean specific activity $1.97 \mathrm{GBq}$ mat. C), and of ${ }^{3} \mathrm{H}$-glucose (specific activity $429 \mathrm{GBq} \mathrm{mmol}^{-1}$, Amersham) were measured basically in the same way as described for measurements of leucine incorporation (see foregoing subsection). Final concentrations of DFAA and added glucose were $0.5 \mathrm{nM}$, respectively. After stopping the incubation, samples were not extracted by ice-cold TCA, but were filtered directly onto $0.45 \mu \mathrm{m}$ nitrocellulose filters, rinsed with particlefree seawater and radioassayed. The CV of the triplicate measurements usually was $<0.10$.

Hydrolytic enzyme activities: Aminopeptidase, $\alpha$-, $\beta$-glucosidase, and chitinase activities of bacteria were measured using fluorogenic substrate analogs (Hoppe 1993). Incubations were performed with Lleucine-methyl coumarinylamide (Fluka) for determination of aminopeptidase activity, 4-methyl-umbelliferyl- $\alpha$ - and $\beta$-D-glucoside (Sigma) for $\alpha$ - and $\beta$-glucosidase activity, and 4-methyl-umbelliferyl- $\beta$-Dglucosaminide (Sigma) for chitinase activity. Hydrolysis was measured in $20 \mathrm{ml}$ samples at $1 \mu \mathrm{M}$ final concentration of the respective substrate analog. This concentration assured maximum hydrolysis rates at in situ temperature in the dark, as determined by satura- tion kinetics. All incubations were run for $2 \mathrm{~h}$ in triplicate and a control was killed with paraformaldehyde ( $4 \%$ final conc.). Fluorescence of all assays was measured in a filter fluorometer (TD 700, Turner Design) at 300 to $400 \mathrm{~nm}$ excitation and 410 to $610 \mathrm{~nm}$ emission. Hydrolytic enzyme activities were calculated after calibration with methyl-coumarinylamide and methyl-umbelliferyl, respectively.

Concentrations of dissolved amino acids and monosaccharides: Concentrations of DFAA were analyzed by high-performance liquid chromatography (HPLC) after ortho-phthaldialdehyde derivatization according to Lindroth \& Mopper (1979) as modified by Simon \& Rosenstock (1992). After prefiltration through a $0.2 \mu \mathrm{m}$ tuffrin filter (Gelman Acrodisc) with low protein-binding capacitiy, samples were stored frozen at $-20^{\circ} \mathrm{C}$ until analysis with a Thermo Separation Product HPLC system after 16 to 17 mo. Dissolved combined amino acids (DCAA) were analyzed as DFAA after hydrolysis with $6 \mathrm{~N} \mathrm{HCl}$ at $100^{\circ} \mathrm{C}$ for $20 \mathrm{~h}$. Concentrations of DFCHO were analyzed by HPLC and pulsed amperometric detection with a DIONEX instrument and a Carbopac PA 10 column according to Mopper et al. (1992) using $20 \mathrm{mM} \mathrm{NaOH}$ as eluent. After prefiltration, samples were stored frozen until analysis after 16 to 17 mo. Prior to analysis, samples were desalted by ion-exchange columns (Mopper et al. 1992, Borch \& Kirchman 1997). Unavoidable losses

Table 1. Sites, station numbers, dates, and locations of Cruise 44/2 of RV 'Meteor' in the Gulf of Aqaba and northern Red Sea between 21 February and 9 March 1999. Station nos. correspond to those in Fig. 1

\begin{tabular}{|c|c|c|c|c|}
\hline \multirow{2}{*}{$\begin{array}{l}\text { Region, } \\
\text { Site }\end{array}$} & \multirow[t]{2}{*}{ Stn No. } & \multirow{2}{*}{ Date } & \multicolumn{2}{|c|}{ Location } \\
\hline & & & $\mathrm{N}$ & E \\
\hline \multicolumn{5}{|c|}{ Gulf of Aqaba } \\
\hline \multirow[t]{4}{*}{ I } & 122 & 22 Feb & $29^{\circ} 29.52^{\prime}$ & $34^{\circ} 57.00^{\prime}$ \\
\hline & 139 & 26 Feb & $29^{\circ} 29.52^{\prime}$ & $34^{\circ} 57.00^{\prime}$ \\
\hline & 151 & 01 Mar & $29^{\circ} 29.46^{\prime}$ & $34^{\circ} 57.18^{\prime}$ \\
\hline & 157 & 05 Mar & $29^{\circ} 29.46^{\prime}$ & $34^{\circ} 57.06^{\prime}$ \\
\hline IV & 125 & $23 \mathrm{Feb}$ & $28^{\circ} 49.98^{\prime}$ & $34^{\circ} 44.04^{\prime}$ \\
\hline \multirow[t]{2}{*}{ VI } & 117 & $21 \mathrm{Feb}$ & $28^{\circ} 20.22^{\prime}$ & $34^{\circ} 33.06^{\prime}$ \\
\hline & 152 & 02 Mar & $28^{\circ} 20.04^{\prime}$ & $34^{\circ} 33.06^{\prime}$ \\
\hline \multicolumn{5}{|c|}{ Northern Red Sea } \\
\hline \multirow[t]{2}{*}{ VII } & 128 & 23 Feb & $27^{\circ} 53.04^{\prime}$ & $34^{\circ} 40.02^{\prime}$ \\
\hline & 144 & 27 Feb & $27^{\circ} 52.80^{\prime}$ & $34^{\circ} 39.96^{\prime}$ \\
\hline VIII & 145 & 27 Feb & $27^{\circ} 39.24^{\prime}$ & $34^{\circ} 40.08^{\prime}$ \\
\hline \multirow[t]{2}{*}{ IX } & 146 & $27 \mathrm{Feb}$ & $27^{\circ} 24.96^{\prime}$ & $34^{\circ} 39.96^{\prime}$ \\
\hline & 154 & 03 Mar & $27^{\circ} 25.08^{\prime}$ & $34^{\circ} 40.38^{\prime}$ \\
\hline \multirow[t]{2}{*}{$\mathrm{X}$} & 131 & $24 \mathrm{Feb}$ & $27^{\circ} 11.04^{\prime}$ & $34^{\circ} 39.96^{\prime}$ \\
\hline & 147 & $28 \mathrm{Feb}$ & $27^{\circ} 10.98^{\prime}$ & $34^{\circ} 39.96^{\prime}$ \\
\hline \multirow[t]{3}{*}{ XII } & 133 & 24 Feb & $27^{\circ} 25.02^{\prime}$ & $34^{\circ} 04.92^{\prime}$ \\
\hline & 149 & 28 Feb & $27^{\circ} 25.02^{\prime}$ & $34^{\circ} 05.04^{\prime}$ \\
\hline & 156 & 04 Mar & $27^{\circ} 24.96^{\prime}$ & $34^{\circ} 04.98^{\prime}$ \\
\hline
\end{tabular}




\section{Northern Gulf (I) Southern Gulf (VI) Red Sea (XII)}
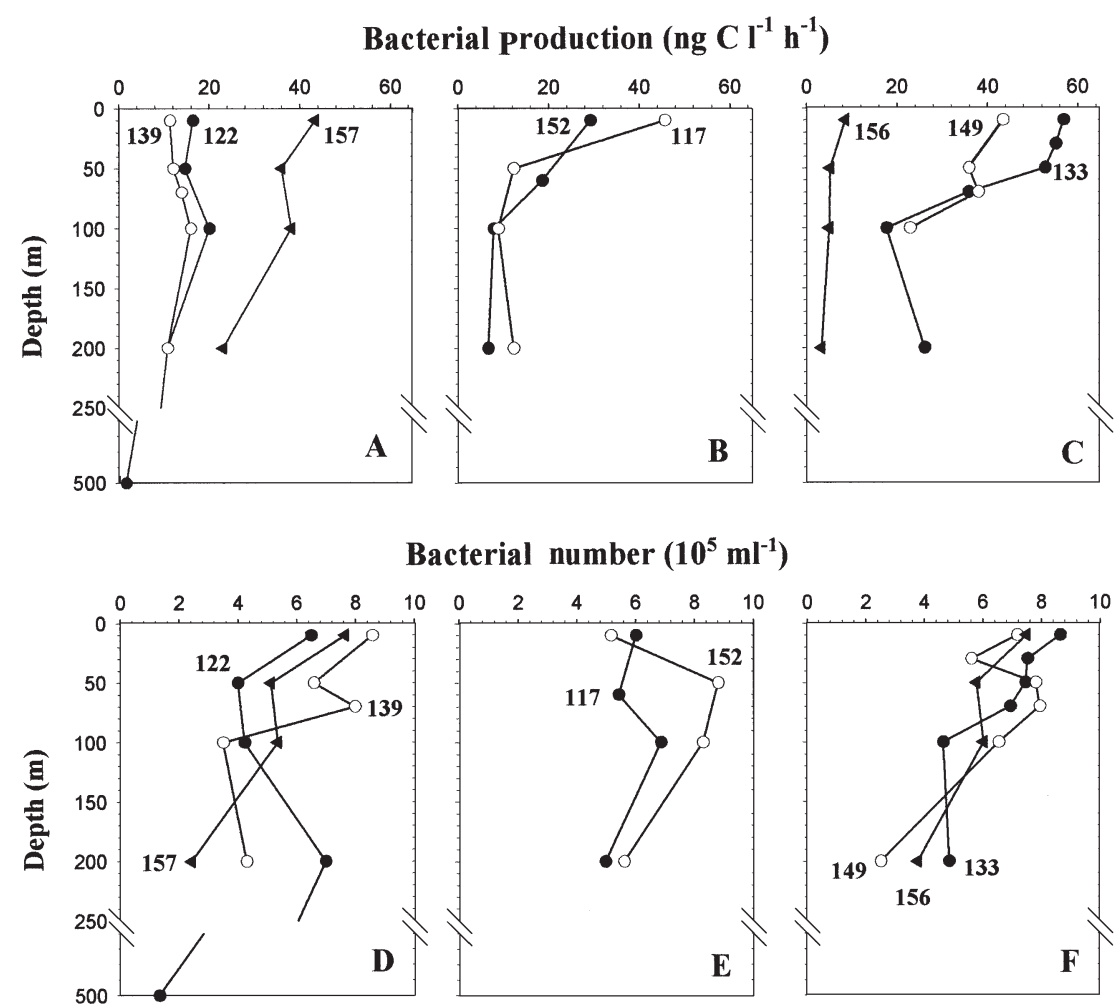

Fig. 2. Bacterial production (A-C) and bacterial numbers (D-F) in northern and southern Gulf of Aqaba and northern Red Sea. Sites, stations and sampling dates as in Table 1

of individual monosaccharides during desalting were corrected for by external standards. Dissolved combined neutral monosaccharides were analyzed as $\mathrm{DFCHO}$ after hydrolysis with $0.09 \mathrm{~N} \mathrm{HCl}$ at $100^{\circ} \mathrm{C}$ for 20 h (Borch \& Kirchman 1997). After hydrolysis, samples were desalted in the same way as those for the DFCHO analysis.

\section{RESULTS}

During our study period we encountered the typical hydrographic situation of winter and early spring, with temperatures of 20 to $23^{\circ} \mathrm{C}$ near the surface and in deep water layers. A strong northeasterly wind (8 to $14 \mathrm{~m} \mathrm{~s}^{-1}$ ) prevailed until 27 February. The Gulf exhibited a mixing regime, with an increasing mixing depth towards its northern end near Aqaba, where it reached $300 \mathrm{~m}$ in the first few days of our investigation. During an intense convection event on 26 February, the mixing depth increased to $550 \mathrm{~m}$ in the northern Gulf. Thereafter it stabilized around $400 \mathrm{~m}$ (Plähn et al. 2000). The northern Red Sea was stratified throughout the investigation period, with an increasing stability towards the southern stations. As long as the northeasterly wind prevailed, the mixed layer in the northern Red Sea remained well-mixed in the upper 50 to $100 \mathrm{~m}$ and allowed an input of nutrients from deeper layers by turbulent diffusion, as indicated by the vertical distribution of inorganic nutrients such as phosphate (M. Badran unpubl. data). When the wind ceased after 28 February, the upper $100 \mathrm{~m}$ became well-stratified with a mixed layer of $<50 \mathrm{~m}$, such that the nutrient input from deeper layers ceased. The different stratification regimes were also reflected in the different vertical and horizontal distributions of chl a. In the northern Gulf the vertical distribution of chl a was homogenous and low $\left(\leq 0.25 \mu \mathrm{g} \mathrm{chl} \mathrm{a} \mathrm{l}^{-1}\right)$, whereas towards the southern part of the Gulf and the northern Red Sea, elevated concentrations of up to $0.43 \mu \mathrm{g} \mathrm{chl} \mathrm{a}$ $\mathrm{I}^{-1}$ occurred in the mixed layer (N. Stambler unpubl. data).

\section{Bacterioplankton growth dynamics}

Bacterioplankton biomass production exhibited pronounced differences in the Gulf of Aqaba and the 
northern Red Sea and thus was consistent with the distribution of chl a. At the northernmost site in the Gulf (Site I), bacterial production remained below $43.4 \mathrm{ng} \mathrm{C} \mathrm{l}^{-1} \mathrm{~h}^{-1}$ in the mixed layer and did not show pronounced vertical variations (Fig. 2A). During the intense mixing event on 26 February (Stn 139), the lowest values occurred. During the first $10 \mathrm{~d}$, bacterial production decreased in the upper $200 \mathrm{~m}$, but exhibited highest values at our last visit to this station on 5 March (Stn 157). In the southern Gulf at Site VI, rates of bacterial production continuously decreased with increasing depth in the upper $100 \mathrm{~m}$ (Fig. 2B). The values at this site were rather similar to bacterial production rates and vertical patterns in the upper $100 \mathrm{~m}$ at Site VII (26.4 to $39.6 \mathrm{ng} \mathrm{C}^{-1} \mathrm{~h}^{-1}$, Stn 128), the northernmost location in the Red Sea (Fig. 1). At Site VI, the upper $200 \mathrm{~m}$ already showed signatures of the northern Red Sea, as indicated by salinity values, and thus suggested an influence of the inflowing Red Sea, surface water on bacterial production at this site. In the northern Red Sea, bacterial production rates in the first week of the investigation were much higher than in the northern Gulf. At Site XII (Stn 133) the highest rates of bacterial production were recorded, reaching $56.8 \mathrm{ng} \mathrm{C} \mathrm{l}^{-1} \mathrm{~h}^{-1}$ (Fig. 2C). In contrast to the Gulf, rates of bacterial production decreased substantially in the northern Red Sea in the second week, except at Site XII, where bacterial production rates strongly decreased only on 4 March (Stn 156). Despite the spatio-temporal differ-

Table 2. Mean $( \pm$ SD) bacterial production $(\mathrm{BP})$, concentrations of dissolved free (DFAA) and combined (DCAA) amino acids and dissolved free neutral (DFCHO) and dissolved combined fee neutral (DCCHO) monosaccharides, turnover rates of DFAA and glucose, uptake of DFAA and DFCHO as percentage of BP, aminopeptidase and $\beta$-glucosidase hydrolysis rates in Gulf of Aqaba and northern Red Sea

\begin{tabular}{|lcc|}
\hline Parameter & Gulf of Aqaba & Northern Red Sea \\
\hline Bacterial production $\left(\mathrm{ng} \mathrm{C}^{-1} \mathrm{~h}^{-1}\right)$ & $17.3 \pm 10.6$ & $21.3 \pm 17.6$ \\
DFAA $(\mathrm{nM})$ & $47.9 \pm 24.0$ & $69.3 \pm 38.1$ \\
DCAA $(\mu \mathrm{M})$ & $1.44 \pm 0.85$ & $1.37 \pm 0.78$ \\
DFCHO $(\mathrm{nM})$ & $18.0 \pm 22.4$ & $3.3 \pm 6.0$ \\
DCCHO $(\mu \mathrm{M})$ & $0.57 \pm 0.60$ & $0.66 \pm 0.48$ \\
DFAA turnover rate $\left(\mathrm{d}^{-1}\right)$ & $0.38 \pm 0.32$ & $0.45 \pm 0.36$ \\
Glucose turnover rate $\left(\mathrm{d}^{-1}\right)$ & $0.045 \pm 0.029$ & $0.049 \pm 0.032$ \\
DFAA uptake $(\% \mathrm{BP})$ & $242.9 \pm 216.5$ & $361.7 \pm 282.4$ \\
DFCHO uptake $(\% \mathrm{BP})$ & $19.5 \pm 32.5$ & $3.1 \pm 5.7$ \\
Aminopeptidase $\left(\mathrm{nmol} \mathrm{l}^{-1} \mathrm{~h}^{-1}\right)$ & $23.2 \pm 21.9$ & $29.9 \pm 28.2$ \\
$\beta$-glucosidase $\left(\mathrm{nmol} \mathrm{l} \mathrm{l}^{-1} \mathrm{~h}^{-1}\right)$ & $19.4 \pm 24.9$ & $22.7 \pm 16.6$ \\
\hline
\end{tabular}

ences, mean values of bacterial production in both study areas were similar (Table 2).

In order to assess bacterial production $\left(\mathrm{m}^{-2} \mathrm{~d}^{-1}\right)$ we integrated bacterial production rates over the upper $150 \mathrm{~m}$ and converted hourly rates to daily rates by multiplication with a factor of 24 . Rates ranged from 20.8 to $128 \mathrm{mgC} \mathrm{m}^{-2} \mathrm{~d}^{-1}$. Highest values (exceeding $90 \mathrm{mgC}$ $\mathrm{m}^{-2} \mathrm{~d}^{-1}$ ) occurred in the northern Red Sea until 28 February and in the Gulf at Site I on March 5 (Fig. 3). On our first visit to the northern Red Sea on 23 and 24 February, rates were substantially higher than in the Gulf. When we revisited the northern Red Sea thereafter, rates were much reduced, except at Site XII (Stn 149). While rates at Site VI in the southern Gulf were fairly similar on 21 February and 2 March, rates at Site I in the Gulf increased 3-fold between 1 and 5 March.

Bacterial numbers ranged between 0.9 and $12.8 \times 10^{5} \mathrm{ml}^{-1}$ and did not exhibit pronounced differences between the Gulf and the northern Red Sea. Horizontal variability in the Gulf was higher than in the northern Red Sea, where numbers, however, consistently decreased with increasing depth (Fig. 2D-F). Bacterial numbers did not show any significant correlation with bacterial production.

Bacterial growth rates were calculated from bacterial production rates and cell numbers, assuming expo- 
nential growth. Rates ranged between $<0.01$ and $0.15 \mathrm{~d}^{-1}$, and thus were rather low. Their vertical and spatial distribution followed that of bacterial production at all stations except Stn 157. While in the northern Gulf values increased towards the end of our study period, they decreased in the northern Red Sea.

\section{Turnover of amino acids and monosaccharides}

Turnover rates of DFAA ranged between $<0.05$ and $1.35 \mathrm{~d}^{-1}$ (Fig. 4A-C), with a mean of 0.38 and $0.45 \mathrm{~d}^{-1}$ in the Gulf and the northern Red Sea, respectively (Table 2). At Site I in the northern Gulf, temporal patterns followed that of bacterial production, with high values at the beginning and the end of our investigation period. In the northern Red Sea, at Site XII lowest DFAA turnover rates were measured on our last visit (Stn 156). Comparing all data, there was a trend of reduced DFAA turnover rates in the northern Red Sea below $100 \mathrm{~m}$ ( 0 to $100 \mathrm{~m}$ : mean of $0.53 \pm 0.36$; >100 m: mean of $0.13 \pm 0.12$ ). In the Gulf this trend was less pronounced ( 0 to $100 \mathrm{~m}$ : mean of $0.41 \pm 0.33 ;>100 \mathrm{~m}$ : mean of $0.30 \pm 0.29$ ). Bacterial production rates were significantly correlated with DFAA turnover rates in the northern Red Sea $\left(r^{2}=0.55, \mathrm{p}<0.05\right)$ but not in the Gulf. Correlations were closer below $100 \mathrm{~m} \mathrm{(r^{2 } = 0 . 7 1 )}$ than above $\left(r^{2}=0.46\right)$.

Turnover rates of glucose ranged between $<0.005$ and $0.14 \mathrm{~d}^{-1}$ (Fig. 4D-F), with a mean of 0.045 and $0.049 \mathrm{~d}^{-1}$ in the Gulf and the northern Red Sea, respectively (Table 2), and thus were 1 order of magnitude lower than those of DFAA. Vertical and spatial patterns in general followed that of DFAA (Fig. 4D-C) turnover rates (Fig. 4D-F), as demonstrated by the highly significant correlation between both parameters $\left(\mathrm{r}^{2}=0.66, \mathrm{p}<0.05\right)$. Bacterial production rates were significantly correlated to glucose turnover rates in the northern Red Sea below $100 \mathrm{~m}\left(\mathrm{r}^{2}=0.55, \mathrm{p}<0.05\right)$, but not above $100 \mathrm{~m}$ and not in the Gulf.

Concentrations of DFAA ranged between 13 and $176 \mathrm{nM}$ (Fig. 5A-C), with means in the Gulf and the northern Red Sea of 47.9 and $69.3 \mathrm{nM}$, respectively (Table 2). In the Gulf, the vertical distribution was more homogenous than in the northern Red Sea. Highest concentrations in the northern Gulf occurred during the convection event on 26 February (Stn 139). Thereafter, concentrations decreased again, showing an inverse trend to the temporal patterns of bacterial production (Fig. 2A). Particularly high values of 70 to

\section{Northern Gulf (I) Southern Gulf (VI) $\quad$ Red Sea (XII)}

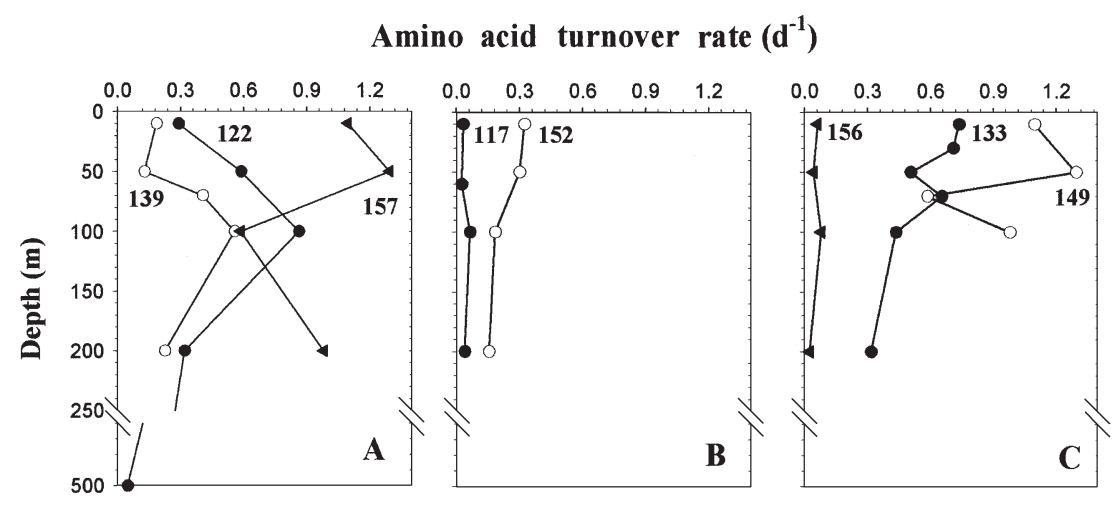

Glucose turnover rate $\left(d^{-1}\right)$

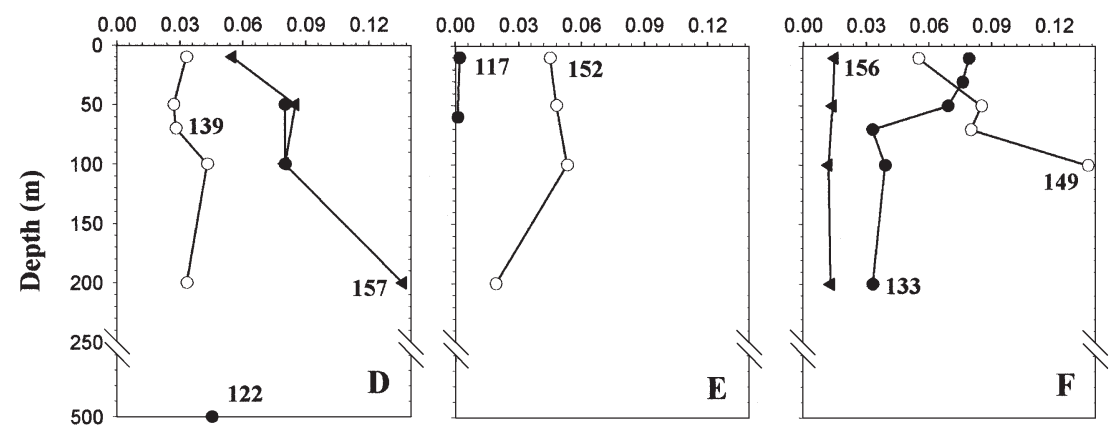

Fig. 4. Amino acid turnover rate $(\mathrm{A}-\mathrm{C})$ and glucose turnover rate $(\mathrm{D}-\mathrm{F})$ in the northern and southern Gulf of Aqaba and northern Red Sea. Sites, stations and sampling dates as in Table 1 


\section{Northern Gulf (I) Southern Gulf (VI) Red Sea (XII)}

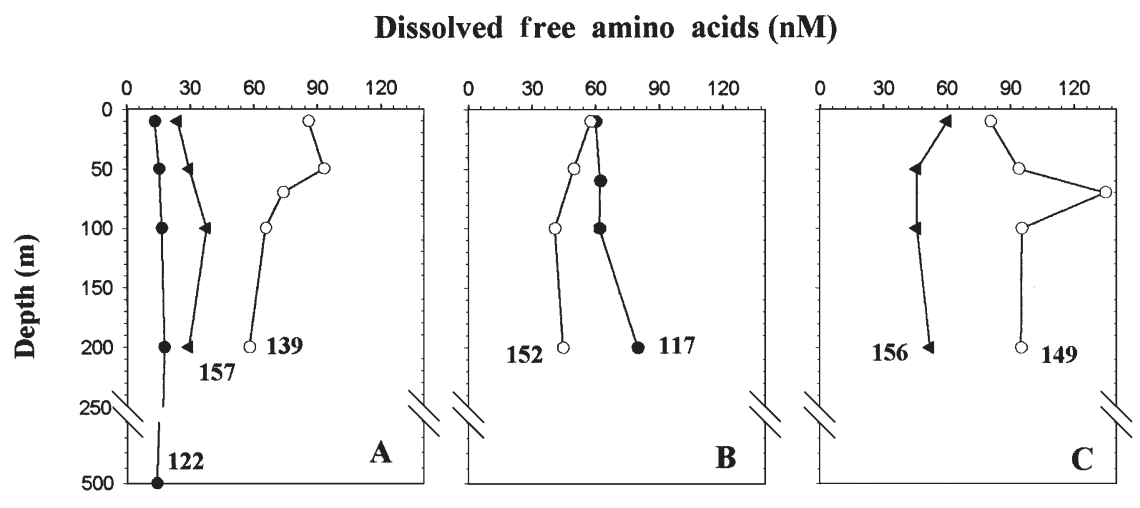

Dissolved free carbohydrates (nM)

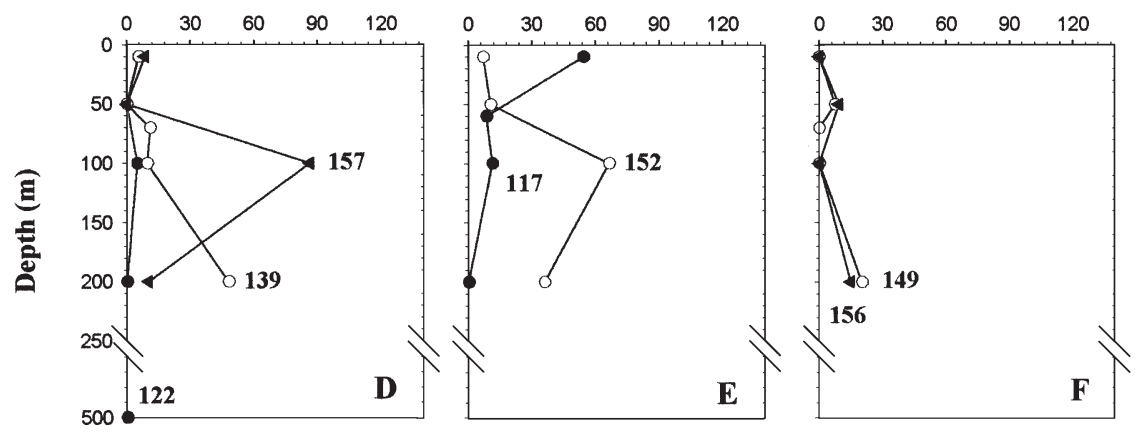

Fig. 5. Dissolved free amino acids (A-C) and dissolved free neutral monosaccharides (D-F) in the northern and southern Gulf of Aqaba and northern Red Sea. Sites, stations and sampling dates as in Table 1

$130 \mathrm{nM}$ were recorded in the upper $200 \mathrm{~m}$ at Site VII. There was no consistent covariation of DFAA concentrations with any other bacterioplankton-related parameter measured. Glycine+threonine and alanine, followed by aspartate, phenylalanine and valine were the dominant single amino acids in all profiles except Stn 147 and 149, where these amino acids constituted nearly similar amounts.

Concentrations of DFCHO were lower than those of DFAA except in 4 cases. They ranged from below the detection limit ( $2 \mathrm{nM}$ ) to $86 \mathrm{nM}$ and remained $<60 \mathrm{nM}$ in $95 \%$ of the cases (Fig. 5D-F). In most profiles, the vertical distribution of $\mathrm{DFCHO}$ concentrations remained fairly constant, but in some cases, such as at Site I (Stns 139, 151, 157), Site VI (Stn 152) and at Site IX (Stn 154), elevated concentrations occurred at $100 \mathrm{~m}$ depth and below. Concentrations of DFCHO in the Red Sea were usually lower than in the Gulf, and were less variable (Table 2). Glucose was the only monosaccharide in 54 of the 58 samples analyzed. In 4 samples galactose and fructose were also detected, but their concentrations did not exceed that of glucose.

Concentrations of DCAA ranged from 0.4 to $3.69 \mu \mathrm{M}$ (amino acid equivalents: Fig. 6A-C), with means of
1.44 and $1.37 \mu \mathrm{M}$ in the Gulf and the northern Red Sea, respectively (Table 2). Vertical distributions of DCAA exhibited some variation, with a tendency of increasing concentrations with increasing depth in the Gulf. In the northern Red Sea, only in 2 cases were elevated concentrations recorded at $100 \mathrm{~m}$ or below. Alanine, serine, glycince+threonine, valine, aspartate, and glutamate were the dominant amino acids in the DCAA pool (Table 3), but their concentrations exhibited some inconsistent variations among the various stations and depths. In both study areas DCAA dominated total dissolved amino acids by $>94 \%$. Concentrations of dissolved combined neutral monosacchorides (DCCHO) ranged from 0.05 to $3.3 \mu \mathrm{M}$ (monosaccharide equivalents: Fig. 6D-F), with means of 0.57 and $0.66 \mu \mathrm{M}$ in the Gulf and the northern Red Sea, respectively (Table 2). Vertical patterns of DCCHO concentrations in general remained fairly homogenous, even though in some cases peaks occurred at individual depths. Only in 1 profile, at Site I in the Gulf (Stn 151) and at a few single depths in the northern Red Sea, were concentrations of DCCHO higher than those of DCAA. Glucose was the dominant monosaccharide in all profiles except Stns 117 and 125, and comprised 30 to 


\section{Northern Gulf (I) Southern Gulf (VI) Red Sea (XII)}

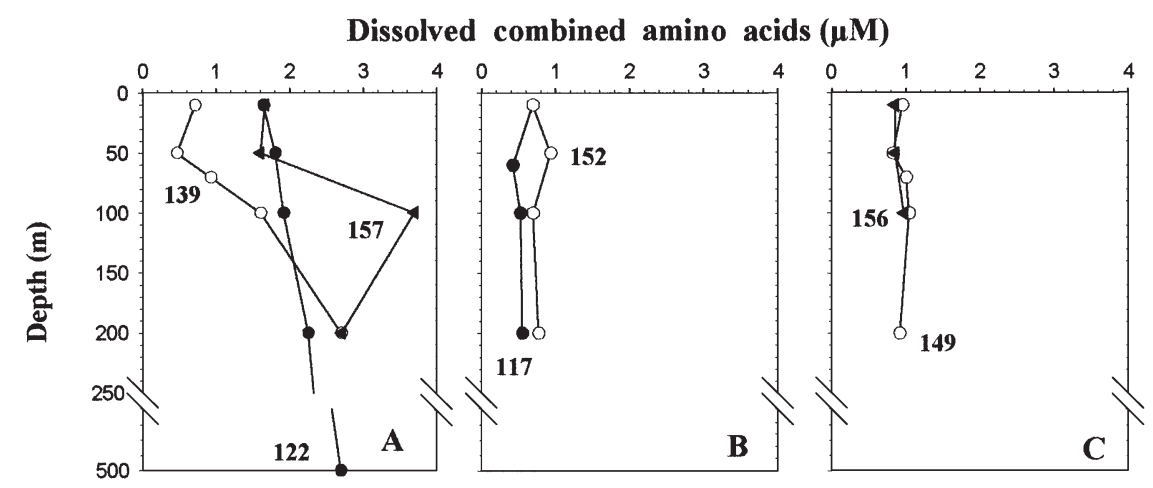

Dissolved combined carbohydrates $(\mu \mathrm{M})$

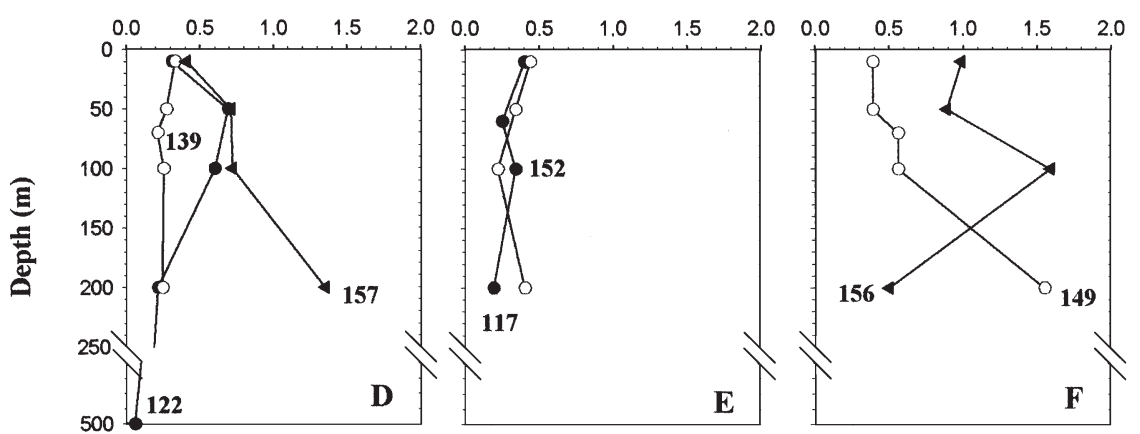

Fig. 6. Dissolved combined amino acids (A-C) and dissolved combined neutral monosaccharides (D-F) in the northern and southern Gulf of Aqaba and northern Red Sea. Sites, stations and sampling dates as in Table 1

$75 \mathrm{~mol} \%$ (mean of 47 and $51 \mathrm{~mol} \%$ ) in the Gulf and the northern Red Sea, respectively (Table 4). Further monosaccharides in the DCCHO pool were galactose, mannose, rhamnose, arabinose, and fucose, which were present in much lower concentrations than glucose. In the profiles of Stns 117 and 125, all the listed monosaccharides were present in fairly equal concentrations, and at some depths, mannose even dominated. DCCHO always dominated the total pool of dissolved neutral monosaccharides by $>96 \%$.

Uptake rates of DFAA were calculated from the turnover rates and the concentrations, and expressed in $\mathrm{C}$ units, assuming $50 \mathrm{~g} \mathrm{C}$ per mol amino acid. They were significantly correlated to bacterial production rates in the northern Red Sea $\left(r^{2}=0.69, p<0.05\right)$, but not in the Gulf. Here we only report uptake rates as percentage of bacterial production. Uptake rates ranged from 20 to $>100 \%$ of bacterial production, with means of 243 and $362 \%$ in the Gulf and the northern Red Sea, respectively (Table 2). Uptake rates of DFCHO were calculated from turnover rates of glucose and concentrations of DFCHO and on the basis of $72 \mathrm{gC}$ per mol monosaccharide. Uptake rates ranged from $<5$ to $>100 \%$ of bacterial production, with means of 19.5 and $3.1 \%$ in the Gulf and the northern Red Sea, respectively (Table 2).
Aminopeptidase hydrolysis rates ranged from $<2$ to $210 \mathrm{nmol} \mathrm{l}^{-1} \mathrm{~h}^{-1}$ (Fig. 7A-C), with means of 23.2 and $29.9 \mathrm{nmol} \mathrm{l}^{-1} \mathrm{~h}^{-1}$ in the Gulf and the northern Red Sea, respectively (Table 2). Highest rates were measured in the northern Red Sea at Site VII (Stn 144) and at Site XII (Stn 149) at $50 \mathrm{~m}$. At all stations, aminopeptidase hydrolysis rates exhibited some vertical variabilities, but no general systematic trend or covariation with other parameters occurred. At Site I in the Gulf, rates increased during the first $10 \mathrm{~d}$ of our investigation period at $50 \mathrm{~m}$ and below, and remained high until the end of our study. In the northern Red Sea, highest rates always occurred in the upper $50 \mathrm{~m}$. Aminopeptidase hydrolysis rates per bacterium ranged from $<0.05$ to 49.2 amol cell $^{-1} \mathrm{~h}^{-1}$. In the northern Red Sea, cellspecific aminopeptidase hydrolysis rates were on average 2.3-fold higher than in the Gulf.

$\beta$-glucosidase hydrolysis rates ranged from $<2$ to 105.2 $\mathrm{nmol} \mathrm{l}^{-1} \mathrm{~h}^{-1}$ (Fig. 7D-F), with means of 19.4 and $22.7 \mathrm{nmol} \mathrm{l}^{-1} \mathrm{~h}^{-1}$ in the Gulf and the northern Red Sea, respectively (Table 2). Highest rates occurred in the Gulf, but values exceeding $40 \mathrm{nmol}^{-1} \mathrm{~h}^{-1}$ occurred also in the northern Red Sea. In the Gulf at Site I enhanced rates occurred at Stn 139 and 151, simultaneously with reduced rates of bacterial production. As for amino- 
peptidase, the vertical and spatial patterns did not covary systematically with those of any other measured parameter. $\beta$-Glucosidase hydrolysis rates per bacterium ranged from $<0.1$ to 43.8 amol cell $^{-1} \mathrm{~h}^{-1}$. In the northern Red Sea, cellspecific $\beta$-glucosidase hydrolysis rates were on average 2.6-fold higher than in the Gulf. $\alpha$-glucosidase hydrolysis rates ranged from $<1$ to $35 \mathrm{nmol} \mathrm{l}^{-1} \mathrm{~h}^{-1}$, and $80 \%$ of the values were below $20 \mathrm{nmol}$ $\mathrm{l}^{-1} \mathrm{~h}^{-1}$ (data not shown). Spatio-temporal patterns did not covary systematically with those of $\beta$-glucosidase. Hydrolysis rates of $\beta$-glucosidase, however, were higher than that of $\alpha$-glucosidase in $89 \%$ of the measured values. The ratio of aminopetidase/ $\beta$-glucosidase varied greatly (from $<0.1$ to 23.5 ), but $92 \%$ of the values were $<10$. Mean values in the Gulf and the northern Red Sea were $4.6 \pm 6.2$ and $2.1 \pm 2.6$, respectively.

\section{DISCUSSION}

This is the first comprehensive report on bacterioplankton growth and substrate dynamics in the oligotrophic Gulf of Aqaba and the Red Sea. The data were collected during early spring, when the Gulf exhibits a deep and increasing mixing regime towards its northern end compared to the stratified northern Red Sea. Many of

Table 4. Composition (mol. \%) of dissolved combined neutral monosaccharides (DCCHO) in the Gulf of Aqaba (Stns 122, 139, 151, 157, 125, 117, 152) and northern Red Sea (Stns 128, 154, 131, 147, 149, 156) between 10 and $200 \mathrm{~m}$ depth

\begin{tabular}{|lrrrrr|}
\hline \multirow{2}{*}{ DCCHO } & \multicolumn{5}{c}{ Depth (m) } \\
& 10 & 50 & 100 & 200 & Mean \\
\hline Gulf of Aquaba & & & & & \\
$\quad$ Fucose & 5.46 & 6.26 & 6.56 & 5.94 & 6.06 \\
Rhamnose & 7.48 & 4.78 & 7.48 & 7.07 & 6.70 \\
Arabinose & 5.70 & 4.74 & 6.58 & 6.31 & 5.84 \\
Galactose & 18.90 & 20.29 & 21.36 & 19.82 & 20.09 \\
Glucose & 43.18 & 51.34 & 44.77 & 50.82 & 47.53 \\
Mannose & 19.11 & 12.57 & 13.78 & 10.04 & 13.88 \\
Northern Red Sea & & & & & \\
Fucose & 5.36 & 4.32 & 5.04 & 3.36 & 4.52 \\
Rhamnose & 5.85 & 6.43 & 0 & 6.17 & 4.61 \\
Arabinose & 6.41 & 5.86 & 7.24 & 6.53 & 6.51 \\
Galactose & 18.93 & 18.12 & 0 & 15.89 & 13.23 \\
Glucose & 52.08 & 55.23 & 46.12 & 51.35 & 51.20 \\
Mannose & 10.87 & 8.97 & 18.82 & 16.69 & 13.84 \\
& & & & & \\
\hline
\end{tabular}

Table 3. Composition (mol. \%) of dissolved combined amino acids (DCAA) in the Gulf of Aqaba (Stns 122, 139, 151, 157, 125, 117, 152) and northern Red Sea (Stns 128, 154, 131, 147, 149, 156) between 10 and $200 \mathrm{~m}$ depth

\begin{tabular}{|lccccc|}
\hline DCAA & \multicolumn{5}{c}{ Depth $(\mathrm{m})$} \\
& 10 & 50 & 100 & 200 & \\
\hline Gulf of Aquaba & & & & & \\
Aspartate & 8.52 & 9.86 & 9.90 & 7.84 & 9.03 \\
Glutamate & 8.76 & 8.48 & 7.42 & 7.19 & 7.96 \\
Serine & 22.38 & 16.62 & 19.23 & 19.08 & 19.33 \\
Histidine & 1.55 & 2.29 & 2.41 & 2.81 & 2.27 \\
Glycine/threonine & 12.88 & 12.82 & 12.62 & 9.99 & 12.08 \\
Arginine & 2.00 & 2.81 & 2.22 & 2.38 & 2.35 \\
Alanine & 15.48 & 16.04 & 15.54 & 17.74 & 16.20 \\
Tyrosine & 5.61 & 4.08 & 4.14 & 5.06 & 4.72 \\
Methionine & 2.61 & 3.83 & 2.97 & 3.11 & 3.13 \\
Valine & 11.73 & 13.12 & 14.72 & 13.12 & 13.17 \\
Phenylalanine & 3.74 & 3.08 & 2.96 & 4.53 & 3.58 \\
Isoleucine & 1.53 & 2.05 & 1.60 & 2.53 & 1.93 \\
Leucine & 2.88 & 4.13 & 3.69 & 3.74 & 3.61 \\
Northern Red Sea & & & & & \\
Aspartate & 8.50 & 8.63 & 9.22 & 8.55 & 8.72 \\
Glutamate & 7.77 & 7.89 & 8.30 & 8.27 & 8.06 \\
Serine & 19.72 & 16.20 & 15.99 & 13.87 & 16.45 \\
Histidine & 1.58 & 2.05 & 2.06 & 2.47 & 2.04 \\
Glycine/threonine & 13.66 & 13.64 & 14.01 & 12.65 & 13.49 \\
Arginine & 2.59 & 3.08 & 2.62 & 2.36 & 2.67 \\
Alanine & 17.27 & 15.88 & 16.19 & 18.56 & 16.98 \\
Tyrosine & 6.09 & 6.57 & 5.55 & 6.21 & 6.10 \\
Methionine & 2.85 & 2.76 & 3.13 & 2.47 & 2.80 \\
Valine & 11.87 & 14.05 & 13.07 & 13.30 & 13.07 \\
Phenylalanine & 3.56 & 4.12 & 4.17 & 5.05 & 4.22 \\
Isoleucine & 1.50 & 1.69 & 2.01 & 1.96 & 1.79 \\
Leucine & 2.86 & 3.15 & 3.49 & 3.70 & 3.30 \\
& & & & & \\
\hline
\end{tabular}

our measured parameters (most clearly the rates of bacterial production) reflected the vertical mixing and stratification regimes in the 2 areas, which also showed some temporal variations. In the stratified northern Red Sea, the range of most parameters related to bacterioplankton growth and substrate dynamics was higher than in the deeply mixed Gulf, covering the lowest as well as (often) the highest values. Further, data from the Gulf were not correlated amongst each other, whereas in the northern Red Sea highly significant correlations existed. This suggests that in the Gulf hydrographic properties, i.e. vertical mixing, were more important in controlling bacterioplankton growth dynamics, whereas in the northern Red Sea biological and, in particular, microbial processes were more important.

Bacterioplankton growth and substrate dynamics in the oligotrophic 


\section{Northern Gulf (I) Southern Gulf (VI) Red Sea (XII)}
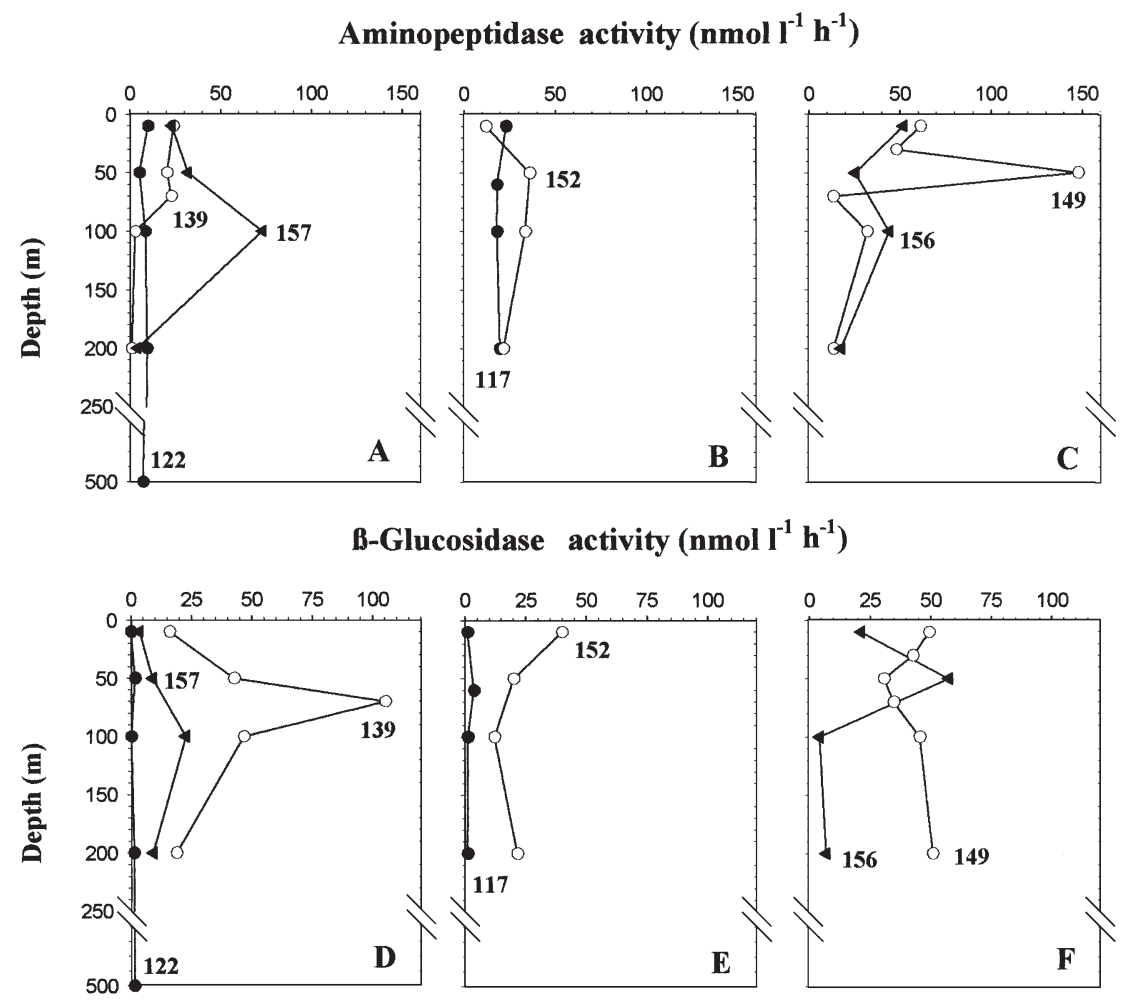

Fig. 7. Aminopeptidase activity (A-C) and $\beta$-glucosidase activity (D-F) in the northern and southern Gulf of Aqaba and northern Red Sea. Sites, stations and sampling dates as in Table 1

Gulf of Aqaba and the northern Red Sea are typical of other oceanic regions of similar trophic state. Our integrated bacterial production rates ranged from 21 and $127 \mathrm{mg} \mathrm{C} \mathrm{m}^{-2} \mathrm{~d}^{-1}$, and were in the range of values measured in the Sargasso Sea (11 to $36 \mathrm{mg} \mathrm{C} \mathrm{m}^{-2} \mathrm{~d}^{-1}$ : Carlson et al. 1996; $117 \mathrm{mg} \mathrm{C} \mathrm{m}^{-2} \mathrm{~d}^{-1}$ : Rivkin \& Anderson 1997), the Caribbean Sea (124 mgC m${ }^{-2} \mathrm{~d}^{-1}$ : Rivkin \& Anderson 1997), the western Indian Ocean (36 to $231 \mathrm{mg} \mathrm{C} \mathrm{m}^{-2} \mathrm{~d}^{-1}$ : Goosen et al. 1997), and the equatorial Pacific (72 to $180 \mathrm{mgC} \mathrm{m}^{-2} \mathrm{~d}^{-1}$ : Kirchman et al. 1995). In summer, chl $a$ increases 2 to 3 times in the stratified northern Gulf compared to early spring, when we conducted our study (Lindell \& Post 1995). Hence, bacterial production rates presumably are also higher in summer, but still in the ranges occurring in other oligotrophic regions. Bacterioplankton growth rates in our study were low $\left(<0.15 \mathrm{~d}^{-1}\right)$ and also well in the range of values reported for other oligotrophic oceanic regions such as the Sargasso Sea, Caribbean Sea, Gulf of Mexico, equatorial and subtropical north Pacific, and the NW Mediterranean Sea (Rivkin \& Anderson 1997, Ducklow 1999, Pedrós-Alió et al. 1999).

The ratio of bacterial production to primary production in oligotrophic oceanic regions does not differ from that in other regions, but may vary substantially depending on the season and the given regional situation (Ducklow 1999). During our cruise, for which primary production data are also available (C. Häse et al. unpubl. data) this ratio also varied greatly (from 0.04 to 1.58) and did not reflect systematic differences between the 2 areas. Highest ratios (1.58 and 0.34) were recorded at Sites X (Stn 131) and I (Stn 139), i.e. at stations with the lowest primary production and with high bacterial production rates. The lowest ratios $(\leq 0.08)$ were recorded at Sites I (Stn 157), IX (Stn 154) and XII (Stn 156) towards the end of the study period, when primary production was 4 - to 10 -fold higher. Whereas at Site I in the Gulf bacterial production increased parallel to but much less steeply than primary production, bacterial production rates in the northern Red Sea decreased, thus emphasizing further the different hydrographic and trophic conditions in the 2 study areas.

The significance of the microbial loop in the trophodynamics in the Gulf of Aqaba and the northern Red Sea has been demonstrated by the dominance of autotrophic picoplankton and eukaryotic algae $<8 \mu \mathrm{m}$ in the phytoplankton (Lindell \& Post 1995). Our data, 
together with data on primary production (C. Häse et al. unpubl. data) provide further evidence of the importance of the microbial loop in this oligotrophic ecosystem. Simultaneous studies on the grazing impact of various zooplankton groups showed that heterotrophic nanoflagellates (HNF) were the major consumers of the heterotrophic bacterioplankton, even though appendicularians were shown to consume up to $10 \%$ of the bacterioplankton production (Sommer et al. 2002). The bacterioplankton grazing rates by HNF measured by Sommer et al. by the dilution technique were balanced by bacterial growth rates, which were higher than ours by a factor of 6 to 9 . The dilution technique requires long (i.e. 24 to $36 \mathrm{~h}$ ) incubation times, and thus may lead to enhanced bacterial growth due to containment effects. Hence, ambient HNF grazing rates may be lower and closer to the bacterial growth rates we measured. The bacterial grazing rates by appendicularians reported by Sommer et al. (2002) were measured in short-term (15 $\mathrm{min})$ incubations using radiolabeled bacteria, and thus presumably resulted in more realistic values than HNF grazing rates. Hence, the significance of appendicularians as bacterioplankton grazers may even be greater than assumed by Sommer et al. (2002). Under conditions of low concentrations of nanoplankton but relatively enhanced concentrations of picoplankton such as in oligotrophic oceanic regions, appendicularians can be very important consumers of picoplankton (Crocker et al. 1991, Acuña et al. 1996).

During the last 10 to $15 \mathrm{yr}$, many studies in various pelagic environments have shown that dissolved amino acids and neutral monosaccharides are the most important substrates for bacterioplankton growth (e.g. Kirchman 1990, Keil \& Kirchman 1993, 1999, Münster 1993, Kirchman et al. 1994, Rich et al. 1996, 1997, Weiss \& Simon 1999, Rosenstock \& Simon 2001). Most evidence stems from measurements of turnover and uptake rates of DFAA, dissolved proteins and DFCHO, together with bacterioplankton production. Our study provides further information from an oligotrophic environment not yet studied in this respect. In contrast to most other studies, we collected simultaneous data on concentrations of DFAA, DCAA, DFCHO and DCCHO, turnover rates of DFAA and glucose, and aminopeptidase and glucosidase activities. This comprehensive data set enables us to estimate the relative significance of dissolved amino acids and monosaccharides for bacterioplankton growth simultaneously; this has rarely been done before.

The concentrations of DFAA we measured varied greatly but did not show any consistent covariation with other parameters measured. Compared to values available from other oligo- and mesotrophic oceanic regions they appear to be rather high. Carlucci et al.
(1984) and Williams (1986) in the Southern California Bight found concentrations of 3 to $80 \mathrm{nM}$, which are nearly in the same range as concentrations reported from the subarctic Pacific (5 to $89 \mathrm{nM}$ : Simon 1991). In the Sargasso Sea concentrations of $<20 \mathrm{nM}$ were reported by Suttle et al. (1991) and Keil \& Kirchman (1999). The only region for which consistently higher values (48 to $233 \mathrm{nM}$ ) were reported is the Arctic Ocean (Rich et al. 1997). Because our concentrations appear rather high and the ratio DFAA uptake rates over bacterial production often exceeded $100 \%$ (Table 2), we cannot exclude the possibility that our samples became contaminated, possibly during prefiltration. Concentrations of DCAA also varied greatly without any clear-cut relationships to other parameters measured. Only a few comparable data from other oceanic regions such as the Southern California Bight and the Sargasso Sea are available, and these are below $0.75 \mu \mathrm{M}$ (Williams 1986, Keil \& Kirchman 1999).

Nearly all concentrations of DFCHO we found were lower than those of DFAA, and were largely dominated by glucose. In the Gulf, concentrations were substantially higher than in the northern Red Sea, where they were often close to the detection limit. The desalting procedure, in addition to ions, removes monosaccharides, e.g. glucose by 37 \% (Borch \& Kirchman 1997). Therefore, samples with low DFCHO concentrations are affected most strongly by the desalting procedure, which may result in an underestimate of DFCHO concentrations. We do not know if our analyses, in particular those in the northern Red Sea, were affected by this methodological bias. Hence, our DFCHO concentrations are conservative. Comparable data on DFCHO concentrations measured by HPLC from oceanic environments are only available for the equatorial Pacific and the Arctic Ocean. In both these regions, higher concentrations were reported, with means ranging from 28 to $137 \mathrm{nM}$ in the equatorial Pacific (Rich et al. 1996) and from 42 to $90 \mathrm{nM}$ in the Arctic Ocean (Rich et al. 1997). As in our study, glucose dominated the DFCHO pool in these areas, in the Arctic Ocean to a higher extent (75\% of total DFCHO) than in the equatorial Pacific (24 to $36 \%$ ). Because identical methods for the desalting and HPLC analysis were used in all studies, we assume that the data from the various oceanic regions exhibit true differences.

Except for 2 depth profiles between 2 and $4000 \mathrm{~m}$ from the equatorial Pacific with a total of 9 isolated values (Skoog \& Benner 1997) our DCCHO concentrations are the only ones available from an oceanic environment that have been analyzed by HPLC after $\mathrm{HCl}$ hydrolysis. Our data are well in the range of those from the equatorial Pacific in the upper $400 \mathrm{~m}$. The distribution $(\mathrm{mol} \%)$ of galactose and mannose in both data sets are also in the same range, but we found higher 
concentrations of glucose and lower concentrations of rhamnose and fucose than Skoog \& Benner in the equatorial Pacific. DCCHO concentrations analyzed by the MBTH (3-methyl-2-benzothiazolinone hydrazone hydrochloride) method after $\mathrm{HCl}$ hydrolysis in the equatorial Pacific, the Gulf of Mexico and the North Atlantic (Pakulski \& Benner 1994) were higher than our values. Hydrolysis with sulphuric acid yields even higher DCCHO concentrations than with $\mathrm{HCl}$, mobilizing more recalcitrant carbohydrates to the detection as monosaccharides (Pakulski \& Benner 1994). This additional fraction of $\mathrm{DCCHO}$, however, presumably is less involved in the biological cycling and not hydrolyzed enzymatically as rapidly as the HCl-hydrolyzable fraction (see below). In most cases, DCCHO concentrations were lower than DCAA concentrations. This is in contrast to the few other reports on simultaneous measurements of concentrations of DCCHO and DCAA from pelagic environments (Williams 1986, Simon et al. 2000), and may be a further indication that our DCAA analyses yielded too high concentrations because of contaminated samples.

Turnover rates of DFAA were closely correlated to those of glucose, but consistently higher. This notion, together with the concentrations and the estimated uptake rates of DFAA and DFCHO, indicates that DFAA were more important than DFCHO as bacterial substrates, irrespective of the possible contamination of the DFAA samples. In support of this, DFAA turnover rates were much better correlated to bacterial production rates, in particular in the northern Red Sea, than DFCHO turnover rates. Our DFAA turnover rates were much lower than values reported for the Sargasso Sea, which ranged from 3 to $8 \mathrm{~d}^{-1}$ (Keil \& Kirchman 1999), but in the same range as values reported from the Arctic Ocean $\left(0.237\right.$ to $0.454 \mathrm{~d}^{-1}$ : Rich et al. 1997). In contrast, our DFCHO turnover rates were about 1 order of magnitude lower than values determined in the equatorial Pacific and the Arctic Ocean by Rich et al. $(1996,1997)$. We do not know whether these differences are due to principal differences in the relative cycling of amino acids and carbohydrates in these ecosystems or whether they reflect seasonal variations. Weiss \& Simon (1999) found in the mixed layer of a mesotrophic lake, that from spring to early summer, DFAA turnover rates were much faster than those of DFCHO, whereas in late summer and fall no difference occurred. Hence, we assume that the differences between turnover rates of DFAA and DFCHO in our study area compared to the other oceanic environments reflect seasonal rather than principal regional differences.

Our DFAA uptake rates (which measured net uptake and not the respired fraction) were surprisingly high, often exceeding $100 \%$ of bacterial production, pre- sumably due to contaminated DFAA samples (see above). Also Rich et al. (1997), for the Arctic Ocean, reported DFAA uptake rates often greatly exceeding bacterial production. In studies of other oceanic environments, the ratio of DFAA uptake over bacterial production ranges between $<20$ and $\sim 60 \%$ (e.g. Simon 1991, Kirchman et al. 1994, Keil \& Kirchman 1999), and presumably is more realistic than the high values we estimated. Nevertheless, these studies, together with ours, emphasize the significance of DFAA as bacterial substrates in oceanic environments. Our uptake rates of DFCHO constituted a lower but still significant fraction of bacterial production. They may have been too low because of a possible underestimate of DFCHO concentrations (see above). The only 2 other studies which determined the significance of DFCHO for bacterial production in oceanic environments found that glucose alone accounted for a higher fraction of bacterial production than ours, ranging from 12 to $122 \%$ of bacterial production (Rich et al. 1996, 1997). Only in the Arctic Ocean did Rich et al. (1997) also simultaneously determine the uptake of glucose and DFAA, and found that DFAA were 2 to 9 times more important as a bacterial substrates than glucose, emphasizing further the relatively higher significance of DFAA compared to DFCHO.

Uptake of DFAA and DFCHO accounts for a significant fraction of the carbon demand for bacterial production, but other substrates may be utilized as well. Keil \& Kirchman $(1993,1999)$ and Rosenstock \& Simon (2001) showed that dissolved proteins are another important substrate for bacterioplankton growth, and can explain percentages of bacterial production exceeding that achieved on DFAA or DFCHO. Polymeric substrates such as proteins and polysaccharides need to be hydrolyzed prior to bacterial uptake as oligo- or monomers, hence hydrolysis rates of aminopeptidase and glucosidases reflect the potential of bacteria to exploit these polymers as substrates. Our results show that potential hydrolysis rates of aminopeptidase and $\beta$-glucosidase, measured at saturating substrate concentrations, were fairly similar, without pronounced differences between the 2 study areas. Whereas the aminopeptidase hydrolysis rates we measured are in the same range as in the few other studies of oceanic environments (Rosso \& Azam 1987, Christian \& Karl 1995, Hoppe \& Ullrich 1999) our $\beta$-glucosidase hydrolysis rates were higher than values for the Indian Ocean (Hoppe \& Ullich 1999), or for the subtropical Pacific and the Gerlache Strait in the Southern Ocean (Christian \& Karl 1995). They were in the same range as values reported for the equatorial Pacific (Christian \& Karl 1995). This suggests that in our study area and the equatorial Pacific, bacteria have a higher potential to exploit $\mathrm{DCCHO}$, which may result in 
reduced concentrations of its available fraction. This suggestion is consistent with the relatively low concentrations of $\mathrm{HCl}$-hydrolyzable DCCHO found in our study area and the equatorial Pacific (Pakulski \& Benner 1994). Pakulski \& Benner found much higher concentrations of $\mathrm{HCl}$-hydrolyzable DCCHO in the Gerlache Strait, where $\beta$-glucosidase activities are low. Similar conclusions of inverse relationships between high hydrolytic activities of $\beta$-glucosidase as well as aminopeptidase and their substrates were drawn from data on limnetic systems (Simon et al. 2000).

It is intriguing that we found such high activities of $\beta$-glucosidase even though turnover rates of glucose, the major hydrolysis product, were rather low. Provided that this finding was not due to methodological biases, (for which we do not have any indication), it suggests that the low DFCHO turnover and uptake was not a response to the high $\beta$-glucosidase activity measured. A possible explanation for this puzzling discrepancy is that $\beta$-glucosidase activities were not associated with bacterial cells, but persisted in a dissolved and active state despite low DCCHO concentrations. Li et al. (1998) found alkaline phosphatase activities persisted for several months in the Gulf of Aqaba in the dissolved state and constituted 42 to $74 \%$ of the total activity. If this were also true for the high $\beta$-glucosidase activities measured in the present study, they would not be directly linked to the ambient rather low bacterial requirements for carbohydrates.

In summary, our results give further evidence of the highly oligotrophic status of the Gulf of Aqaba and northern Red Sea. Bacterioplankton growth and substrate dynamics in the stratified northern Red Sea were more variable and appeared to be more driven by biological processes, whereas at the well-mixed northernmost station in the Gulf hydrographic properties appeared to be more important. Our comprehensive findings are comparable to those of the few other studies of oceanic regions with similar trophic regimes. They emphasize the importance of amino acids as substrates for bacterioplankton growth, whereas carbohydrates appear to be less important. On the other hand, the high $\beta$-glucosidase activities we found suggest that, at times, carbohydrates may be more important for bacterioplankton growth. In order to better understand the relative significance of amino acids and carbohydrates in the trophodynamics of bacterioplankton growth in such nutrient-depleted oceanic systems, more comprehensive data sets are needed.

Acknowledgements. We would like to thank the crew of RV 'Meteor' for their excellent support on shipboard. We are most grateful to N. Selje, who assisted in nearly all experimental work on board, day and night, and to Birgit Kürzel for the carbohydrate analyses. We appreciate the cooperation of
M. Badran, C. Häse, and N. Stambler in making available unpublished data on inorganic nutrients, primary production, and chlorophyll $a$, respectively. This work was supported by grants from the Deutsche Forschungsgemeinschaft awarded to G. Hempel and M.S.

\section{LITERATURE CITED}

Acuña JL, Deibel D, Morris CC (1996) Particle capture mechanism of the pelagic tunicate Oikopleura vanhoeffeni. Limnol Oceanogr 41:1800-1814

Azam F, Fenchel T, Field JG, Gray JS, Meyer-Reil LA, Thingstad F (1983) The ecological role of water-column microbes in the sea. Mar Ecol Prog Ser 10:257-263

Borch NH, Kirchman DL (1997) Concentration and composition of dissolved combined neutral sugars (polysaccharides) in seawater determined by HPLC-PAD. Mar Chem 57:85-95

Buck KR, Chavez FP, Campbell L (1996) Basin-wide distributions of living carbon components and the inverted trophic pyramid of the central gyre of the North Atlantic Ocean, summer 1993. Aquat Microb Ecol 10:283-298

Carlson C, Ducklow HW, Sleeter TD (1996) Stocks and dynamics of bacterioplankton in the northwestern Sargasso Sea. Deep-Sea Res Part II 43:491-516

Carlucci AF, Craven DB, Henrichs SM (1984) Diel production and microheterotrophic utilization of dissolved free amino acids in waters off southern California. Appl Environ Microbiol 48:165-170

Christian JR, Karl DM (1995) Bacterial ectoenzymes in marine waters: activity ratios and temperature responses in three oceanographic provinces. Limnol Oceanogr 40:1042-1049

Crocker KM, Alldredge AL, Steinberg DK (1991) Feeding rates of the doliolid, Dolioletta gegenbauri, on diatoms and bacteria. J Plankton Res 13:77-82

Deibel D (1982) Laboratory-measured grazing and ingestion rates of the salp, Thalia democratica Forksal and Dolioletta gegenbauri Uljanin (Tunicata, Thaliacea). J Plankton Res 4:189-201

Ducklow HW (1993) Bacterioplankton distributions and production in the northwestern Indian Ocean and Gulf of Oman. September 1986. Deep-Sea Res 40:753-771

Ducklow HW (1999) The bacterial component of the oceanic euphotic zone. FEMS Microbiol Ecol 30:1-10

Eppley RW, Peterson BJ (1979) Particulate organic matter flux and planktonic new production in the deep ocean. Nature 282:677-680

Goosen NK, van Rijswijk P, DeBie M, Peene J, Kromkamp J (1997) Bacterioplankton abundance and production and nanozooplankton abundance in Kenyan coastal waters (Western Indian Ocean). Deep-Sea Res Part II 44: $1235-1250$

Hoppe HG (1993) Use of fluorogenic model substrates for extracellular enzyme activity (EEA) measurements of bacteria. In: Kemp PF, Sherr BF, Sherr EB, Cole JJ (eds) Handbook of methods in aquatic microbial ecology. Lewis Publishers, Boca Raton, FL, p 423-432

Hoppe HG, Ullrich S (1999) Profiles of ectoenzymes in the Indian Ocean: phenomena of phosphatase activity in the mesopelagic zone. Aquat Microb Ecol 19:139-148

Keil RG, Kirchman DL (1993) Dissolved combined amino acids: chemical forms and utilization by marine bacteria. Limnol Oceanogr 38:1256-1270

Keil RG, Kirchman DL (1999) Utilization of dissolved protein and amino acids in the northern Sargasso Sea. Aquat Microb Ecol 18:293-300 
Kirchman DL (1990) Limitation of bacterial growth by dissolved organic matter in the subarctic Pacific. Mar Ecol Prog Ser 62:47-54

Kirchman DL, K'nees E, Hodson RE (1985) Leucine incorporation and its potential as a measure of protein synthesis by bacteria in natural systems. Appl Environ Microbiol 49: 599-607

Kirchman DL, Ducklow HW, McCarthy JJ, Garside C (1994) Biomass and nitrogen uptake by heterotrophic bacteria during the spring phytoplankton bloom in the North Atlantic Ocean. Deep-Sea Res Part I 41:879-895

Kirchman DL, Rich JH, Barber RT (1995) Biomass and biomass production of heterotrophic bacteria along $140^{\circ} \mathrm{W}$ in the equatorial Pacific: effect of temperature on the microbial loop. Deep-Sea Res Part II 42:603-619

Li H, Veldhuis MJW, Post AF (1998) Alkaline phosphatase activities among planktonic communities in the northern Red Sea. Mar Ecol Prog Ser 173:107-115

Li WKW, Dickie PM, Irwin BD, Wood AM (1992) Biomass of bacteria, cyanobacteria, prochlorophytes, and photosynthetic eukaryotes in the Sargasso Sea. Deep-Sea Res 39: 501-519

Lindell D, Post AF (1995) Ultraphytoplankton succession is triggered by deep winter mixing in the Gulf of Aqaba (Eilat), Red Sea. Limnol Oceanogr 40:1130-1141

Lindroth P, Mopper K (1979) High performance liquid chromatographic determinations of subpicomole amounts of amino acids by precolumn fluorescence derivatization with o-phthaldialdehyde. Anal Chem 51:1667-1674

Mopper K, Schultz CA, Chevolot L, Germain C, Revuelta R, Dawson R (1992) Determinations of sugars in unconcentrated seawater and other natural waters by liquid chromatography and pulsed amperometric detection. Environ Sci Technol 26:133-138

Münster U (1993) Concentrations and fluxes of organic carbon substrates in the aquatic environment. Antonie Leeuwenhoek 63:243-274

Pakulski JD, Benner R (1994) Abundance and distribution of carbohydrates in the ocean. Limnol Oceanogr 39:930-940

Pedrós-Alió C, Calderón-Paz JI, Guixa-Boixereu N, Estrada M, Gasol JM (1999) Bacterioplankton and phytoplankton biomass and production during summer stratification in the northwestern Mediterranean Sea. Deep-Sea Part I 46: 985-1019

Plähn O, Badran M, El-Deek M, Sangok Y, Badewien T, Elbrächter M, Manasreh R, Walter M (2000) Physical and chemical oceanography: hydrography and tracer measurements. In: Pätzold J, Halbach PE, Hempel G, Weikert $\mathrm{H}$ (eds) Meteor Bericht 00-3: Östliches MittelmeerNördliches Rotes Meer 1999, Cruise No. 44, Hamburg, p 59-62

Porter KG, Feig YS (1980) The use of DAPI for identifying and counting aquatic microflora. Limnol Oceanogr 25:943-948

Reiss Z, Hottinger L (1984) The Gulf of Aqaba: ecological micropaleontology. Springer-Verlag, Berlin

Rich JH, Ducklow HW, Kirchman DL (1996) Concentrations and uptake of neutral monosaccharides along $140^{\circ} \mathrm{W}$ in the equatorial Pacific: contribution of glucose to hetero-

Editorial responsibility: Gotthilf Hempel,

Bremen, Germany trophic bacterial activity and the DOM-flux. Limnol Oceanogr 41:595-604

Rich JH, Gosselin M, Sherr EB, Sherr BF, Kirchman DL (1997) High bacterial production, uptake and concentration of dissolved organic matter in the Central Arctic Ocean. Deep-Sea Res II 44:1645-1663

Rivkin RB, Anderson MR (1997) Inorganic nutrient limitation of oceanic bacterioplankton. Limnol Oceanogr 42: $730-740$

Rosenstock B, Simon M (2001) Sources and sinks of dissolved free amino acids and protein in a large and deep mesotrophic lake. Limnol Oceanogr 46:644-654

Rosso AL, Azam F (1987) Proteolytic activity in coastal oceanic waters: depth distribution and relationship to bacterial populations. Mar Ecol Prog Ser 41:231-240

Simon M (1991) Isotope dilution of intracellular amino acids as a tracer of carbon and nitrogen sources of marine planktonic bacteria. Mar Ecol Prog Ser 74:295-301

Simon M, Azam F (1989) Protein content and protein synthesis rates of planktonic marine bacteria. Mar Ecol Prog Ser 51:201-213

Simon M, Rosenstock B (1992) Carbon and nitrogen sources of planktonic bacteria in Lake Constance studied by the composition and isotope dilution of intracellular amino acids. Limnol Oceanogr 37:1496-1511

Simon M, Jontofsohn M, Parparov A, Berman T (2000) Turnover of combined amino acids and carbohydrates on organic aggregates and in the bulk water in Lake Kinneret and other pelagic ecosystems. Arch Hydrobiol Spec Issue Adv Limnol 55:365-377

Skoog A, Benner R (1997) Aldoses in various size fractions of marine organic matter: implications for carbon cycling. Limnol Oceangr 42:1803-1813

Sommer U (2000) Scarcity of medium-sized phytoplankton in the Red Sea explained by strong bottom-up and weak topdown control. Mar Ecol Prog Ser 197:19-25

Sommer U, Berninger UG, Böttger-Schnack R, SchnackSchiel SB and 8 others (2002) Grazing during early spring in the Gulf of Aqaba and the northern Red Sea. Mar Ecol Prog Ser 239:251-261

Suttle CA, Chan AM, Fuhrman JA (1991) Dissolved free amino acids in the Sargasso Sea: uptake and respiration rates, turnover times, and concentrations. Mar Ecol Prog Ser 70:189-199

Weiss M, Simon M (1999) Consumption of labile dissolved organic matter by limnetic bacterioplankton: the relative significance of amino acids and carbohydrates. Aquat Microb Ecol 17:1-12

Weisse T (1989) The microbial loop in the Red Sea: dynamics of pelagic bacteria and heterotrophic nanoflagellates. Mar Ecol Prog Ser 55:241-250

Williams PM (1986) Chemistry of the dissolved and particulate phases in the water column. In: Eppley RW (ed) Lecture notes on coastal and estuarine studies, SpringerVerlag, Berlin, Heidelberg, New York, Tokyo, p 51-83

Wolf-Vecht A, Paldor N, Brenner S (1992) Hydrographic indications of advection/convection effects in the Gulf of Eilat. Deep-Sea Res 39:1393-1401

Submitted: May 3, 2001; Accepted: January 31, 2002 Proofs received from author(s): July 18, 2002 